\title{
Cold Atmospheric Plasma as a Novel Method for Inactivation of Potato Virus Y in Water Samples
}

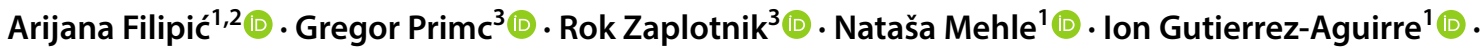

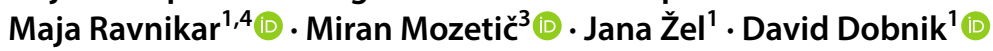

Received: 23 January 2019 / Accepted: 16 April 2019 / Published online: 29 April 2019

(c) The Author(s) 2019

\begin{abstract}
While one of the biggest problems we are facing today is water scarcity, enormous quantities of water are still being used in irrigation. If contaminated, this water can act as an effective pathway for the spread of disease-causing agents, like viruses. Here, we present a novel, environmentally friendly method known as cold atmospheric plasma for inactivation of viruses in water used in closed irrigation systems. We measured the plasma-mediated viral RNA degradation as well as the plasmainduced loss of viral infectivity using potato virus $\mathrm{Y}$ as a model virus due to its confirmed water transmissibility and economic as well as biological importance. We showed that only $1 \mathrm{~min}$ of plasma treatment is sufficient for successful inactivation of viruses in water samples with either high or low organic background. The plasma-mediated inactivation was efficient even at markedly higher virus concentrations than those expected in irrigation waters. Obtained results point to reactive oxygen species as the main mode of viral inactivation. Our laboratory-scale experiments confirm for the first time that plasma has an excellent potential as the eukaryotic virus inactivation tool for water sources and could thus provide a cost-effective solution for irrigation mediated plant virus transmission. The outstanding inactivation efficiency demonstrated by plasma treatments in water samples offers further expansions of its application to other water sources such as reused wastewater or contaminated drinking waters, as well as other plant, animal, and human waterborne viruses, ultimately leading to the prevention of water scarcity and numerous human, animal, and plant infections worldwide.
\end{abstract}

Keywords Cold atmospheric plasma $\cdot$ Potato virus $\mathrm{Y} \cdot$ Virus inactivation $\cdot$ Water decontamination

Electronic supplementary material The online version of this article (https://doi.org/10.1007/s12560-019-09388-y) contains supplementary material, which is available to authorized users.

Arijana Filipić

arijana.filipic@nib.si

1 Department of Biotechnology and Systems Biology, National Institute of Biology, Večna pot 111, 1000 Ljubljana, Slovenia

2 Jožef Stefan International Postgraduate School, Jamova cesta 39, 1000 Ljubljana, Slovenia

3 Department of Surface Engineering and Optoelectronics, Jožef Stefan Institute, Jamova cesta 39, 1000 Ljubljana, Slovenia

4 University of Nova Gorica, Vipavska 13, 5000 Nova Gorica, Slovenia

\section{Introduction}

The availability of clean water is in continued decline due to the increasing global population and food demand, along with higher standards of living and climate change (WWAP 2018). Water scarcity has an important impact on the environment as it affects aquatic organisms, groundwater-dependent terrestrial ecosystems as well as plants and humans (Pfister et al. 2011). Over the past 4 years, water scarcity has been regarded as one of the highest global risks, in terms of its potential impact on humanity (World Economic Forum 2017). Despite this, 70\% of water use worldwide goes on account of irrigation (WWAP 2018). This makes agriculture a major environmental burden in terms of water use (Ridoutt et al. 2018). To tackle this important global problem, closed irrigation systems that recycle water, such as hydroponic systems, are becoming more common. However, such systems can serve as a route for efficient and rapid transmission of pathogens in case of water source 
contamination. Plant pathogens can reduce seed germination, affect the yield and even destroy entire crops (Syed Ab Rahman et al. 2018).

Water-transmissible viruses are especially problematic, as they are usually resistant to wastewater treatment processes (Carducci et al. 2009) and common disinfection methods that have been developed to target mostly bacteria. Moreover, viruses can survive in water for long periods of time, can be infectious at low doses, and are the source of numerous human, animal and plant infections and epidemics (Mehle and Ravnikar 2012; Shrestha et al. 2018). Potato virus Y (PVY) is a water-transmissible plant virus that can successfully spread through irrigation systems (Mehle et al. 2014). PVY is, economically and scientifically speaking, one of the 10 most important plant viruses worldwide (Scholthof et al. 2011) and the most important potato viral pathogen which can cause up to $80 \%$ loss in crop production (Kogovšek et al. 2016). PVY isolates from the recombinant $P V Y^{\text {NTN }}$ group are the most devastating and cause mosaic, chlorotic, and necrotic lesions on leaves as well as necrotic ringspots on tubers (Kogovšek et al. 2016). High losses in potato yield pose a big problem since potato is one of the most important crops in the world (FAO 2018). In addition to potato, PVY can also infect other important crops, such as tobacco, tomato, and pepper (Scholthof et al. 2011).

Removal of viruses from irrigation systems is possible, but typically used methods can be expensive [membrane filtration, heating, ultraviolet (UV) light, ozonation], time consuming (slow filtration), require large infrastructure (slow filtration, heat), frequent maintenance (slow filtration, UV light, ozonation), produce undesirable side components (chlorination, ozonation), or need additional decontamination steps (some types of slow filtration, UV light) (Stewart-Wade 2011). The greatest weakness of all chemical processes for water decontamination is the generation of toxic by-products as well as production, transport and handling of large amounts of dangerous decontaminants. The main limitation of physical methods is that they are effective only in water areas that are in the close proximity of the operating device (Kraft 2008). Of all the disinfection methods, only thermal disinfection has been proven to be suitable for inactivation of plant viruses in hydroponic production systems (Bandte et al. 2016). Thus it is extremely important to develop and implement efficient and environmentally friendly approaches for water decontamination that do not require toxic chemicals and can be scaled up. One of the technologies that might fulfill these requirements is cold atmospheric plasma (CAP).

Plasma is the fourth state of matter and it is generated by applying energy to a gas. It is a mixture of charged particles (i.e., ions, free electrons), reactive species, UV photons, and neutral particles (i.e., molecules, atoms in the excited or ground state). Due to some of these components, with the emphasis on the reactive chemical species, CAP has great antimicrobial potential (Guo et al. 2015). The temperature of CAP at the point of application is usually $<40{ }^{\circ} \mathrm{C}$, which makes it suitable for treating biological samples (Hoffmann et al. 2013). CAP devices for decontamination have been tested for various applications, such as in medicine and food processing, where they have been shown to be effective (Scholtz et al. 2015). They have also been used for degradation of non-biological (Bansode et al. 2017) and biological, mostly bacterial (Rashmei et al. 2016), contaminants in water. Although some studies of CAP-virus interactions have already been performed (for review see Pradeep and Chulkyoon 2016) only one brief study has examined the effects of CAP on a plant virus, tobacco mosaic virus (Hanbal et al. 2018), and only one study has described bacteriophage inactivation in water samples by CAP (Guo et al. 2018).

The aim of the present study was to evaluate the applicability of CAP for inactivation of viruses in water from closed irrigation systems. We chose PVY ${ }^{\mathrm{NTN}}$ as the model virus because of its demonstrated water transmissibility and economic relevance. We showed that CAP can inactivate high concentrations of $\mathrm{PVY}^{\mathrm{NTN}}$ in nutrient solution after only $1 \mathrm{~min}$ of treatment and suggested that the inactivation is mainly mediated by the formation of reactive oxygen species.

\section{Materials and Methods}

For schematic representation of the experimental design, see Fig. 1.

\section{Virus Source}

We used two sources of viruses in nutrient solution to create an approximation to water samples of different complexities that represent those used in closed irrigation systems. Plants infected with PVY ${ }^{\mathrm{NTN}}$ were homogenized and diluted in nutrient solution to provide the complex infected water samples (henceforth referred to as 'infected homogenate'). The less complex infected water samples contained only purified PVY ${ }^{\text {NTN }}$ (Online Resource 1a) diluted in nutrient solution. Ultracentrifugation-purified virus particles had lower concentration (henceforth referred to as 'low concentration pure virus') than chromatography-purified virus particles (henceforth referred to as 'high concentration pure virus'). Untreated samples of infected homogenate and both types of pure virus were used as positive controls.

Each infected homogenate was prepared by grinding $88 \pm 3 \mathrm{mg}$ of the green parts (i.e., leaves and stems) of potato plants (Solanum tuberosum cv. 'Pentland Squire') grown in vitro cultures and infected with $\mathrm{PVY}^{\mathrm{NTN}}$. This was 
Fig. 1 Schematic representation of the experimental design

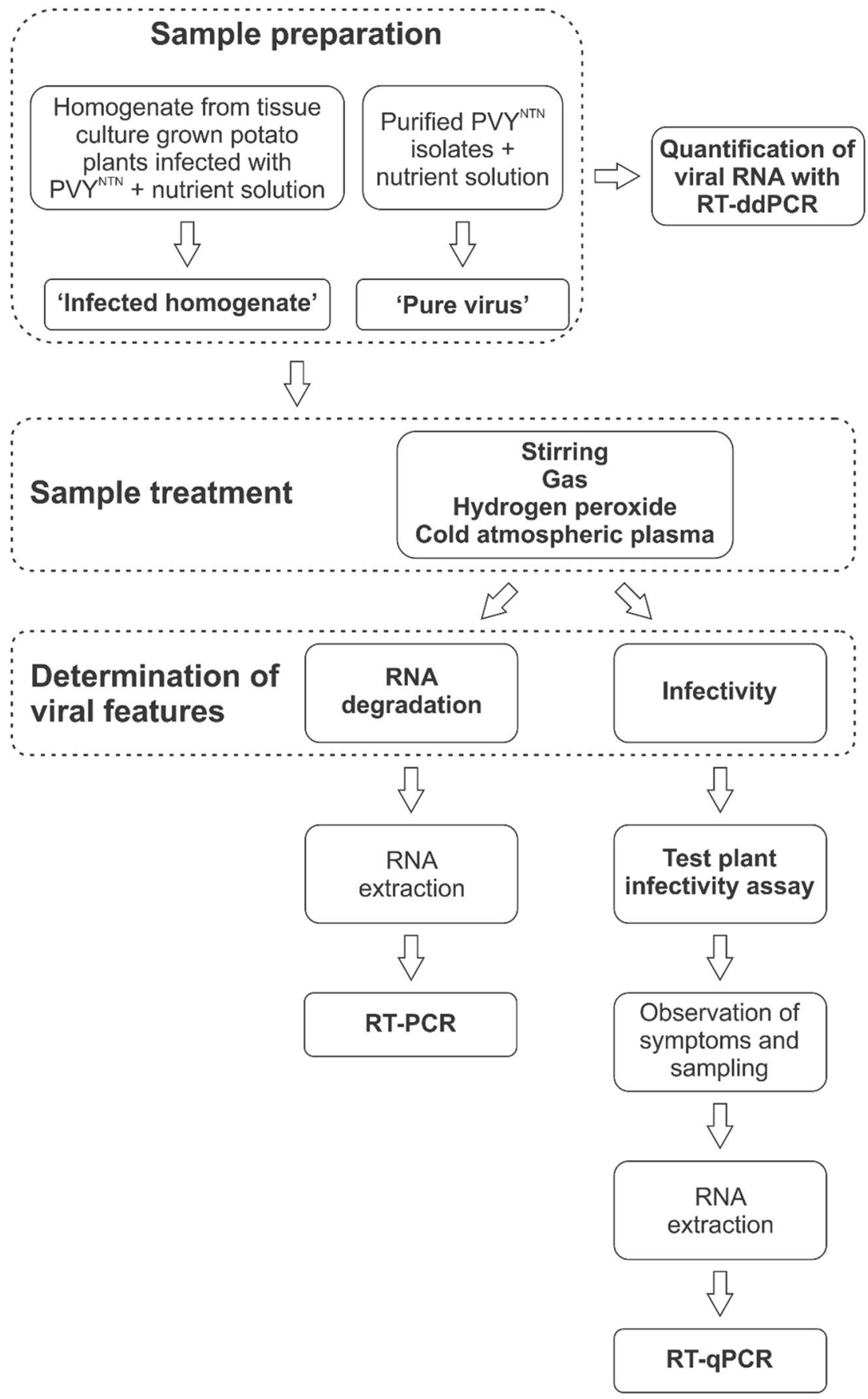

then mixed with $20 \mathrm{~mL}$ nutrient solution that consisted of tap water with added minerals (Johnson et al. 1994). We divided each of the infected homogenates into two samples of $10 \mathrm{~mL}$ : one that served as a positive control and was not treated further, and the other that was treated with hydrogen peroxide $\left(\mathrm{H}_{2} \mathrm{O}_{2}\right)$ (control treatment, various concentrations) or CAP (various times).

For isolation of the pure viruses, $\mathrm{PVY}^{\mathrm{NTN}}$-infected tobacco and potato tissues from plants grown in the soil were prepared by grinding them in chilled (to $4{ }^{\circ} \mathrm{C}$ ) grinding buffer. PVY ${ }^{\mathrm{NTN}}$ was then purified using either a standard purification method that included saccharose and $\mathrm{CsCl}$ gradient ultracentrifugation (low concentration pure virus) or convective interaction media (CIM) monolithic chromatography (high concentration pure virus) (Rupar et al. 2013). We added the low concentration pure virus particles to $10 \mathrm{~mL}$ nutrient solution and then either left the sample untreated (positive controls) or treated it with simple magnetic stirring (control treatment), gas treatment (control treatment with the gas mixture used for CAP production, 
but in the absence of CAP), $\mathrm{H}_{2} \mathrm{O}_{2}$ (control treatment, various concentrations and times), or CAP (various times). The high concentration pure virus particles stayed untreated (positive control) or underwent CAP treatments (various times).

The viral RNA for all of the virus preparations was quantified prior to their treatments using reverse-transcription droplet digital PCR (RT-ddPCR). RT-ddPCR was performed with One-Step RT-ddPCR advanced kit for probes (Bio-Rad, USA) as described by Mehle et al. (2018) with minor modifications i.e., thresholds of 2400 were not always used during analyses and data with $<10,000$ droplets were not discarded.

\section{CAP Source Characterization and Treatment}

We used a CAP system in the single electrode configuration to investigate the inactivation of PVY $\mathrm{PTN}^{\mathrm{NT}}$ in the infected samples (Fig. 2). CAP was created using a mixture of argon $(\sim 99 \%)$ and oxygen $(\sim 1 \%)$, with a constant flow rate of $1 \pm 0.2 \mathrm{~L} / \mathrm{min}$. The plasma or only the gas mixture was introduced into the infected samples using a perforated quartz glass tube. A copper electrode was inserted in the tube and connected to a low-frequency generator $(31 \mathrm{kHz})$ that operated at a peak-to-peak voltage of $6 \mathrm{kV}$, with total average output power of $\sim 3 \mathrm{~W}$.
We performed treatments of the infected homogenates using CAP for $5,15,30$, and $45 \mathrm{~min}$, and $1 \mathrm{~h}$ in two repeats. Treatments of $2 \mathrm{~h}$ and $3 \mathrm{~h}$ were performed in a single repeat. We treated both low and high concentration pure virus using CAP for 1, 5, and $10 \mathrm{~min}$ in a single repeat.

Optical emission spectroscopy (OES) was used to observe the light emitted by the plasma during the treatments. An Avantes AvaSpec-3648 optical spectrometer with a resolution of $0.5 \mathrm{~nm}$ from 200 to $1100 \mathrm{~nm}$ was used. The integration time was set to $1 \mathrm{~s}$. We measured spectra during CAP treatments of various samples: nutrient solution, low concentration pure virus, and infected homogenate. Additionally, as a control, the OES spectrum of CAP treatment without sample (CAP in the air) was recorded (Fig. 3).

\section{Control Treatments}

We used a series of control treatments to confirm that any effect on the PVY ${ }^{\mathrm{NTN}}$ arose from the CAP treatments. The first two control treatments consisted of either stirring of the low concentration pure virus on the magnetic stirrer for $1 \mathrm{~min}$ or treating it for $1 \mathrm{~min}$ with the gas mixture used for CAP production, but in the absence of CAP. The next stage control treatment included the addition of $\mathrm{H}_{2} \mathrm{O}_{2}$ to
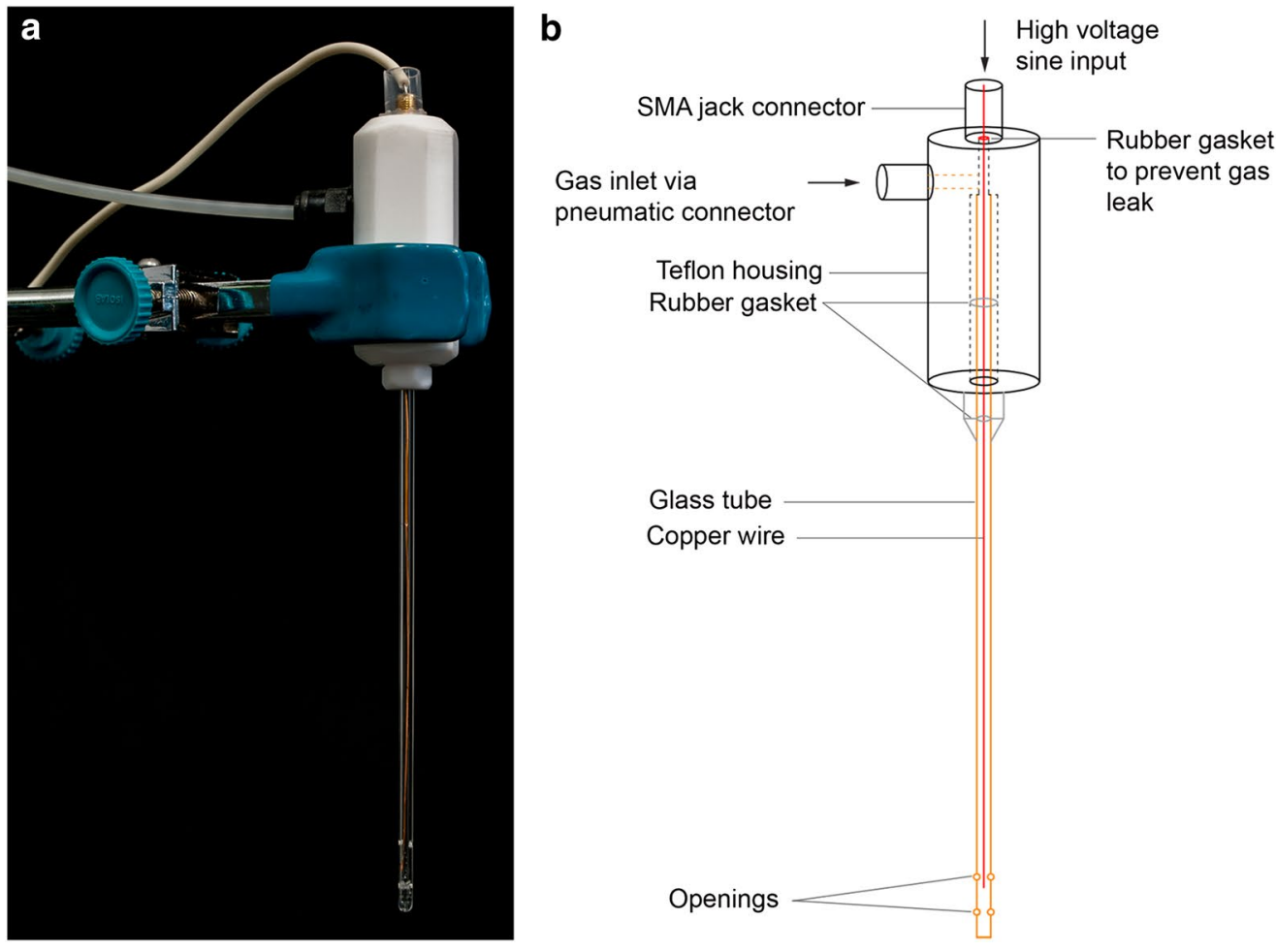

Fig. 2 Production of cold atmospheric plasma (CAP). a Single electrode cold atmospheric plasma jet and $\mathbf{b}$ its schematic representation. c CAP treatment of a sample, during which the plasma streamers produced can be seen, as the blue-white structures in the lower

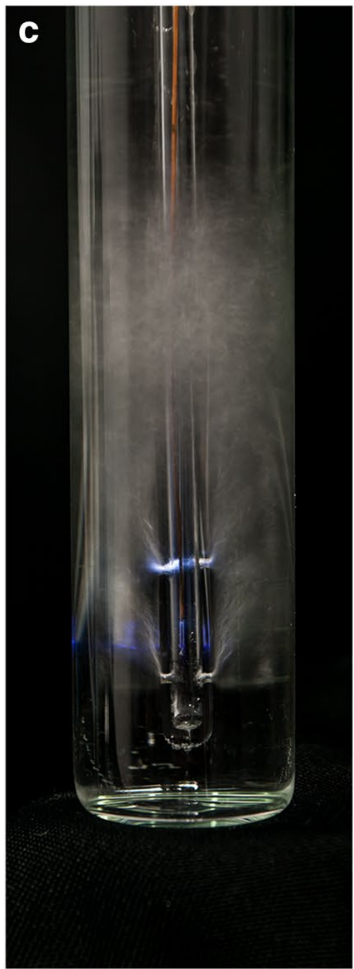

part of the panel. The CAP enters the samples in the form of bubbles (blurred part of the panel) through four openings, two on each side of the glass tube (Color figure online) 


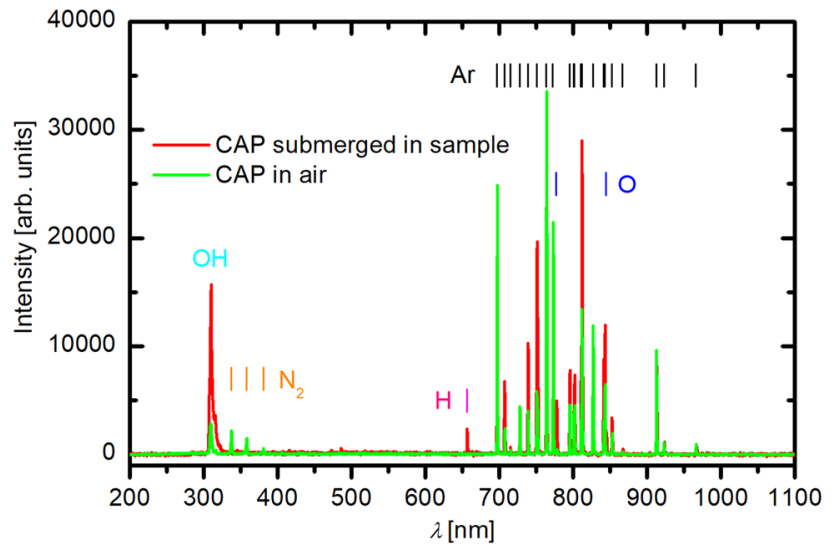

Fig. 3 An OES spectra of a submerged CAP during treatment of low concentration pure virus and CAP in the air, in the absence of a sample. Vertical lines of the same color represent spectral print of chemical species: light blue is for $\mathrm{OH}$, yellow for $\mathrm{N}_{2}$, pink for $\mathrm{H}$, dark blue for $\mathrm{O}$, and black for $\mathrm{Ar}$ (Color figure online)

the samples. We applied $\mathrm{H}_{2} \mathrm{O}_{2}$ at final concentrations of $12.5 \mathrm{mg} / \mathrm{L}$ and $25 \mathrm{mg} / \mathrm{L}$ for $15 \mathrm{~min}$ with constant stirring for the infected homogenates. For the low concentration pure viruses, we applied $\mathrm{H}_{2} \mathrm{O}_{2}$ at final concentrations of $0.5 \mathrm{mg} / \mathrm{L}$ and $1 \mathrm{mg} / \mathrm{L}$ for $1 \mathrm{~min}$ and $25 \mathrm{mg} / \mathrm{L}$ for $15 \mathrm{~min}$ with constant stirring. Used $\mathrm{H}_{2} \mathrm{O}_{2}$ concentrations reflected those found to be present after various CAP treatments (see Online Resources 2 and 3).

\section{Reverse-Transcription PCR}

To examine the effects of different treatments on degradation of viral RNA, we first extracted the PVY ${ }^{\mathrm{NTN}}$ RNA from samples. RNeasy plant minikit (Qiagen, Germany) was used for RNA extractions from infected homogenates according to the manufacturer's instructions, with minor modifications, namely, without using mercaptoethanol. RNA extractions from the pure virus were carried out with QIAmp Viral RNA minikit (Qiagen), according to the manufacturer's instructions, with minor modifications, namely, luciferase RNA (2 $\mathrm{ng} / \mathrm{sample}$ ) was added to the carrier RNA prior to extraction as an external control and the final elution step was performed with $45 \mu \mathrm{L}$ of RNAse-free water. Sterile water was used as negative control of the extraction to monitor for potential contaminations during all extractions.

After the extractions RNA was amplified for the following four PVY ${ }^{\mathrm{NTN}}$ genes using reverse-transcription polymerase chain reaction (RT-PCR): P1 and P3 (which code for proteins involved in virus replication), NIa (which codes for a serine-like cysteine protease), and $\mathrm{CP}$ (which codes for the coat protein) (Table 1; Online Resource 1b). This selection of the viral genes enabled us to cover different parts of the viral genome. RT-PCR was prepared using One-Step RTPCR kit (Qiagen), protocol without Q-solution, according to the manufacturer's instructions, with minor modifications, namely, smaller volume reactions were prepared and $5 \mu \mathrm{L}$ of template RNA was used. The cycling conditions were $30 \mathrm{~min}$ at $50{ }^{\circ} \mathrm{C}, 15 \mathrm{~min}$ at $95{ }^{\circ} \mathrm{C}, 35$ cycles of $30 \mathrm{~s}$ at $94^{\circ} \mathrm{C}, 1 \mathrm{~min}$ at $52{ }^{\circ} \mathrm{C}$ and $1 \mathrm{~min}$ at $72{ }^{\circ} \mathrm{C}, 7 \mathrm{~min}$ at $72{ }^{\circ} \mathrm{C}$, and an infinite hold at $4{ }^{\circ} \mathrm{C}$. Sterile water was used as a non-template control of RT-PCR reactions to monitor possible contaminations of the PCR reagents. We detected the amplified PCR products using agarose gel electrophoresis and considered RNA as degraded, if at least one of the four targeted genes was not amplified.

\section{Test Plant Infectivity Assay}

We used test plant infectivity assays to examine the PVY ${ }^{\mathrm{NTN}}$ infectivity in water samples after the control and CAP treatments. We mechanically inoculated two leaves of individual tobacco (Nicotiana tabacum, cv. 'White Burley') plants with nutrient solution (negative control), positive controls or treated samples. The inoculation process and growth

Table 1 Targeted genes and corresponding oligonucleotide sequences used in RT-PCR

\begin{tabular}{lr}
\hline Targets & Oligonucleotide sequences \\
\hline P1 (codes for protein involved in virus replication) & P1_FW: 5'-ATG GCA ACT TAC ACA TCA ACA ATC CAG-3' \\
P3 (codes for protein involved in virus replication) & P1_R: 5'-TTA TTG AGT AAC CTT GGA ACG TGC ATC A-3' \\
NIa (codes for a serine-like cysteine protease) & P3_FW: 5'-ATG GGT ATT CCT AAT GCA TGC CCT-3' \\
& P3_R: 5'-TTA CTG GTG TCG CAC ATC ATA TTC TTC C-3' \\
& NIa_FW: 5'-ATG GCC AAA TCA CTC ATG AGA GGT TTA \\
CP (codes for the coat protein) & AG-3' \\
& NIa_R: 5'-TTA TTG CTC TAC AAC AAC ATC ATG ATC ATC C-3' \\
& AP_FW: 5'-ATG GGA AAT GAC ACA ATC GAT-3' \\
\hline
\end{tabular}

All oligonucleotides were designed within presented study. All oligonucleotides were purchased from Integrated DNA Technologies, USA

$F W$ forward oligonucleotides, $R$ reverse oligonucleotides 
conditions for the tobacco plants were as described in Mehle et al. (2014).

We regularly inspected test plants for development of symptoms of PVY ${ }^{\mathrm{NTN}}$ infection (Online Resource 1c), and confirmed viral infectivity and systemic spreading using reverse-transcription real-time (quantitative) PCR (RTqPCR). We sampled two developed non-inoculated upper leaves $14 \pm 1$ days and $32 \pm 1$ days post-inoculation, and pooled together all of the plant material from the plants inoculated with the same sample. We then extracted the RNA with RNeasy plant minikit according to the manufacturer's instructions, with minor modifications i.e., without using mercaptoethanol and the final RNA elution was carried out with $150 \mu \mathrm{L}$ of RNAse-free water. After that we performed RT-qPCR using AgPath-ID One-Step RT-qPCR mix (Ambion, USA), as described by Mehle et al. (2014) with minor modifications particularly, reactions were run in duplicates and all RNA samples were analyzed undiluted and diluted 10-fold to avoid inhibitory effects.

\section{Results and Discussion}

The present study is the first one in the field of the eukaryotic virus inactivation by CAP for the purpose of water decontamination. Besides examining applicability of CAP for virus inactivation in contaminated water samples, we also investigated the most probable mode of viral inactivation.

Complete loss of virus infectivity (total inactivation) was achieved in 17 out of 18 CAP treatments (Table 2). Only one repeat of the infected homogenate treated by CAP for 5 min contained infective PVY ${ }^{\mathrm{NTN}}$, which we detected in the upper non-inoculated leaves of the test plants. We detected $\mathrm{PVY}^{\mathrm{NTN}}$ in all of the plants inoculated with the positive

Table 2 Different treatments of water samples and their effects on the RNA and the viral infectivity

\begin{tabular}{|c|c|c|c|c|c|}
\hline Virus sources & $\begin{array}{l}\text { Treatment } \\
\text { types }\end{array}$ & $\begin{array}{l}\text { Treatment conditions } \\
\text { (concentration and/or time) }\end{array}$ & $\begin{array}{l}\text { Viral RNA concentration } \\
(\text { copies } / \mu \mathrm{L} \text { of sample })^{\mathrm{a}}\end{array}$ & $\begin{array}{l}\text { Viral RNA } \\
\text { degradation }^{\mathrm{b}}\end{array}$ & $\begin{array}{l}\text { Viral } \\
\text { infectivity }^{\mathrm{c}}\end{array}$ \\
\hline \multirow[t]{9}{*}{ Infected homogenate } & \multirow[t]{2}{*}{$\mathrm{H}_{2} \mathrm{O}_{2}$} & $12.5 \mathrm{mg} / \mathrm{L}, 15 \mathrm{~min}$ & $4.5 \times 10^{5}$ & - & + \\
\hline & & $25 \mathrm{mg} / \mathrm{L}, 15 \mathrm{~min}$ & & - & + \\
\hline & \multirow[t]{7}{*}{ CAP } & $5 \min ^{\mathrm{d}}$ & $7.42 \times 10^{5} / 1.5 \times 10^{6}$ & - & $+/-^{\mathrm{e}}$ \\
\hline & & $15 \min ^{\mathrm{d}}$ & $7.7 \times 10^{5} / 4.4 \times 10^{5}$ & $+/-^{\mathrm{e}}$ & - \\
\hline & & $30 \min ^{\mathrm{d}}$ & $5.6 \times 10^{5} / 6.5 \times 10^{5}$ & + & - \\
\hline & & $45 \min ^{\mathrm{d}}$ & $4.2 \times 10^{5} / 1.3 \times 10^{6}$ & + & - \\
\hline & & $1 \mathrm{~h}^{\mathrm{d}}$ & $3.6 \times 10^{6} / 6.0 \times 10^{6}$ & - & - \\
\hline & & $2 \mathrm{~h}$ & $1.8 \times 10^{6}$ & - & - \\
\hline & & $3 \mathrm{~h}$ & $2.0 \times 10^{6}$ & + & - \\
\hline \multirow[t]{8}{*}{ Low concentration pure virus ${ }^{f}$} & Stirring & $1 \mathrm{~min}$ & $4.0 \times 10^{4}$ & - & + \\
\hline & Gas & $1 \mathrm{~min}$ & & - & + \\
\hline & \multirow[t]{3}{*}{$\mathrm{H}_{2} \mathrm{O}_{2}$} & $0.5 \mathrm{mg} / \mathrm{L}, 1 \mathrm{~min}$ & & - & + \\
\hline & & $1.0 \mathrm{mg} / \mathrm{L}, 1 \mathrm{~min}$ & & - & + \\
\hline & & $25 \mathrm{mg} / \mathrm{L}, 15 \mathrm{~min}$ & & - & - \\
\hline & \multirow[t]{3}{*}{ CAP } & $1 \mathrm{~min}$ & $2.7 \times 10^{4}$ & - & - \\
\hline & & $5 \min$ & & + & - \\
\hline & & $10 \mathrm{~min}$ & & + & - \\
\hline \multirow[t]{3}{*}{ High concentration pure virus ${ }^{\mathrm{g}}$} & \multirow[t]{3}{*}{ CAP } & $1 \mathrm{~min}$ & $2.7 \times 10^{5}$ & - & - \\
\hline & & $5 \mathrm{~min}$ & & - & - \\
\hline & & $10 \mathrm{~min}$ & & + & - \\
\hline
\end{tabular}

CAP cold atmospheric plasma treatment

${ }^{\mathrm{a}}$ Viral concentration were determined in positive controls

${ }^{\mathrm{b}} \mathrm{RNA}$ was considered as degraded $(+)$ if at least one of the four targeted genes was not amplified

${ }^{\mathrm{c}}$ Viruses were considered infective (+) if we detected them with RT-qPCR in upper, non-inoculated leaves of test plants 2 and/or 4 weeks after the inoculation

${ }^{\mathrm{d}}$ Two repeats of CAP treatments were performed

${ }^{\mathrm{e}}$ One repeat positive $(+)$, other repeat negative $(-)$

${ }^{\mathrm{f}} \mathrm{PVY} \mathrm{YTN}^{\mathrm{NTN}}$ purified from infected tobacco or potato tissue using a classic purification method that included saccharose and $\mathrm{CsCl}$ gradient ultracentrifugation

${ }^{\mathrm{g}} \mathrm{PVY}{ }^{\mathrm{NTN}}$ purified from infected tobacco or potato tissue using CIM monolithic chromatography 
control samples, while we have seen no PVY ${ }^{\mathrm{NTN}}$ infections for plants inoculated with the negative control (nutrient solution). Minimum time needed for inactivation of viruses in infected homogenate was $5 \mathrm{~min}$, whereas only $1 \mathrm{~min}$ was needed for inactivation of pure virus both in high and low concentration. We speculated that difference in inactivation times originated from the amount of organic matter present in the infected homogenate, which can absorb the plasma irradiation and as such might 'protect' viruses from it i.e., viruses might become less accessible to the irradiation. The most obvious proof that CAP interacts with plant organic matter was a discoloration of samples in the first few minutes of treatments (Online Resource 4). Additional cause for the difference could be varied initial amount of virus in the samples, which was determined using RT-ddPCR. Concentrations of PVY ${ }^{\mathrm{NTN}}$ in the infected homogenate ranged from $4.2 \times 10^{5}$ to $6 \times 10^{6} \mathrm{RNA}$ copies/ $\mu \mathrm{L}$ of sample, while for the low and high concentration of pure virus, average determined concentrations were $3.6 \times 10^{4}$ and $2.7 \times 10^{5}$ RNA copies/ $\mu \mathrm{L}$ of sample, respectively (Table 2 ).

Treated samples were tested for the presence of intact viral RNA by monitoring four targeted genes. We showed that the PVY ${ }^{\text {NTN }}$ RNA was successfully degraded by the CAP treatments after $15 \mathrm{~min}$ for the infected homogenate, and after $5 \mathrm{~min}$ for low concentration pure virus (Table 2). RNA was not degraded in any of the positive controls. Since RNA was not degraded in all of the experiments in which infectivity was abolished, it is likely that CAP also damages viral coat proteins, which destabilizes the virus particles. Indeed, coat protein damage alone might be enough to inactivate viruses. This is supported by the findings of different research groups which showed that coat protein damage after CAP treatment was a main mode of inactivation of different bacteriophages and mammalian viruses: bacteriophage lambda and MS2, human adenovirus and feline calicivirus (Aboubakr et al. 2018; Wu et al. 2015; Yasuda et al. 2010; Zimmermann et al. 2011).

To confirm that the viral inactivation was due to CAP treatment, we used control treatments that included $\mathrm{H}_{2} \mathrm{O}_{2}$, gas, or stirring. None of them had any effects on the PVY ${ }^{\text {NTN }}$ RNA degradation, for either the infected homogenate or the pure virus (Table 2). Moreover, in the infectivity assays, across all of the control treatments, only the highest $\mathrm{H}_{2} \mathrm{O}_{2}$ treatment $(25 \mathrm{mg} / \mathrm{L})$ of the pure virus for $15 \mathrm{~min}$ effectively reduced the PVY ${ }^{\mathrm{NTN}}$ infectivity. However, the same treatment did not affect the PVY ${ }^{\mathrm{NTN}}$ infectivity in the infected homogenate (Table 2). This can be explained by either higher availability of the organic material (including viruses) in the infected homogenate with which the $\mathrm{H}_{2} \mathrm{O}_{2}$ can interact or by the presence of the plant enzymes in the infected homogenate that can degrade the $\mathrm{H}_{2} \mathrm{O}_{2}$ (Zámocký et al. 2012). The data for $\mathrm{H}_{2} \mathrm{O}_{2}$ as a control treatment confirm its implication in plasma-mediated virus inactivation.
However, the greater PVY ${ }^{\mathrm{NTN}}$ inactivation obtained with CAP, compared to $\mathrm{H}_{2} \mathrm{O}_{2}$ alone, suggests that other plasma components are also involved in this CAP-mediated PVY ${ }^{\mathrm{NTN}}$ inactivation.

We confirmed this with the OES measurements (Fig. 3) where we observed increased concentration of $\mathrm{OH}$ and $\mathrm{O}$ species that probably served as the precursors for production of different reactive oxygen species. Ar, $\mathrm{O}$, and $\mathrm{H}$ atoms emission lines and $\mathrm{OH}$ emission system $\left(\mathrm{A}^{2} \Sigma^{+}-\mathrm{X}^{2} \Pi\right)$ were observed for all CAP treatments (Online Resource 5). The presence of $\mathrm{OH}$ emission system and Balmer $\mathrm{H}$ emission line in the OES spectra proves that water vapor is dissociated in the plasma. The intensities of spectral features did not change during the treatments, regardless of the sample type. A new spectral feature, $\mathrm{N}_{2}$ emission bands, can be seen only in the OES spectrum of CAP in the air. These are present due to the diffusion of the ambient air into the plasma stream. The $\mathrm{OH}$ is also present in the free air CAP because of the humidity in the ambient air. However, the $\mathrm{OH}$ intensity is much smaller compared to the submerged CAP, thus indicating that the water from the samples is evaporated and dissociated in the plasma. We did not detect any response in the range between 200 and $300 \mathrm{~nm}$, the wavelengths at which UV radiation damages nucleotides in different ways (USEPA 2006). That is why we concluded that UV radiation could not have any impact on the virus inactivation. This leaves reactive oxygen species as the crucial CAP components of viral inactivation, an argument supported by various research groups (reviewed in Guo et al. 2015).

We have performed here a pioneering study using CAP treatment for eukaryotic virus inactivation in water samples. The use of CAP in our experiments effectively inactivated $\mathrm{PVY}^{\mathrm{NTN}}$ in water samples, both in combination with the high organic background from the plant debris (infected homogenate) and in the pure PVY ${ }^{\mathrm{NTN}}$ form. The inactivation was efficient even though the PVY ${ }^{\text {NTN }}$ genome concentrations were significantly higher than those expected in irrigation waters (Mehle et al. 2014). These new findings confirm the potential that CAP treatments hold in the field of virus inactivation in irrigation water. They also lay the groundwork to further studies on other waterborne viruses of plant, animal and human origins, and on the opportunities for the scaling up of these CAP treatments. Plasma systems might also prove useful for decontamination of other water sources, such as wastewater, drinking water, and water for recreational use. Implementation of plasma systems in wastewater treatment plants would significantly reduce their running and maintenance costs, and the space required (Barillas 2015). That might prove to be an excellent alternative for many countries that reuse wastewater for irrigation without prior disinfection due to economic limitations and the scarcity of fresh water supplies (Moazeni et al. 2017). Implementation of plasma systems might thus have 
important positive effects on water quality and might provide solutions that are greatly needed today. To make this implementation as smooth as possible, additional studies are required to define the exact mechanism(s) of action and whether CAP treated water can have any effects on human, animal, and plant cells.

Acknowledgements This work was financially supported by the Slovenian Research Agency (Research Core Funding No. P4-0407, Project No. L4-9325 and program for young researchers in the accordance with » agreement on (co) financing research activity in 2018 «No. 100018-0105), Ministry of Agriculture, Forestry and Food and DomžaleKamnik Wastewater Treatment Plant.We want to thank Dr. Matevž Rupar for designing the oligonucleotides used in the PCR assay and Dr. Magda Tušek Žnidarič for providing representative transmission electron microscopy micrograph of PVY ${ }^{\mathrm{NTN}}$. The study was performed using ddPCR equipment financed by the Metrology Institute of the Republic of Slovenia (MIRS), with financial support from the European Regional Development Fund. This equipment is wholly owned by the Republic of Slovenia.

\section{Compliance with Ethical Standards}

Conflict of interest The authors declare that they have no conflict of interest.

Open Access This article is distributed under the terms of the Creative Commons Attribution 4.0 International License (http://creativeco mmons.org/licenses/by/4.0/), which permits unrestricted use, distribution, and reproduction in any medium, provided you give appropriate credit to the original author(s) and the source, provide a link to the Creative Commons license, and indicate if changes were made.

\section{References}

Aboubakr, H. A., Mor, S. K., Higgins, L. A., Armien, A., Youssef, M. M., Bruggeman, P. J., et al. (2018). Cold argon-oxygen plasma species oxidize and disintegrate capsid protein of feline calicivirus. PLoS ONE, 13(3), 1-24.

Bandte, M., Rodriguez, M. H., Schuch, I., Schmidt, U., \& Buettner, C. (2016). Plant viruses in irrigation water: Reduced dispersal of viruses using sensor-based disinfection. Irrigation Science, 34(3), 221-229.

Bansode, A. S., More, S. E., Siddiqui, E. A., Satpute, S., Ahmad, A., Bhoraskar, S. V., et al. (2017). Effective degradation of organic water pollutants by atmospheric non-thermal plasma torch and analysis of degradation process. Chemosphere, 167, 396-405.

Barillas, L. (2015). Design of a prototype of water purification by plasma technology as the foundation for an industrial wastewater plant. Journal of Physics: Conference Series, 591, 1-8.

Carducci, A., Battistini, R., Rovini, E., \& Verani, M. (2009). Viral removal by wastewater treatment: Monitoring of indicators and pathogens. Food and Environmental Virology, 1(2), 85-91.

FAO. (2018). Retrieved May 22, 2018, from http://www.fao.org/faost at/en/\#data/QC.

Guo, J., Huang, K., \& Wang, J. (2015). Bactericidal effect of various non-thermal plasma agents and the influence of experimental conditions in microbial inactivation: A review. Food Control, 50, 482-490.

Guo, L., Xu, R., Gou, L., Liu, Z., Zhao, Y., Liu, D., et al. (2018). Mechanism of virus inactivation by cold atmospheric-pressure plasma and plasma-activated water. Applied and Environmental Microbiology, 84(17), 1-10.

Hanbal, S. E., Takashima, K., Miyashita, S., Ando, S., \& Ito, K. (2018). Atmospheric-pressure plasma irradiation can disrupt tobacco mosaic virus particles and RNAs to inactivate their infectivity. Archives of Virology, 163(10), 2835-2840.

Hoffmann, C., Berganza, C., \& Zhang, J. (2013). Cold Atmospheric plasma: Methods of production and application in dentistry and oncology. Medical Gas Research, 3(1), 21.

Johnson, J. F., Allan, D. L., \& Vance, C. P. (1994). Phosphorus stress-induced proteoid roots show altered metabolism in Lupinus albus. Plant Physiology, 104(2), 657-665.

Kogovšek, P., Pompe-Novak, M., Petek, M., Fragner, L., Weckwerth, W., \& Gruden, K. (2016). Primary metabolism, phenylpropanoids and antioxidant pathways are regulated in potato as a response to potato virus $\mathrm{Y}$ infection. PLOS ONE, 11(1), 1-20.

Kraft, A. (2008). Electrochemical water disinfection: A short review. Platinum Metals Review, 52(3), 177-185.

Mehle, N., Dobnik, D., Ravnikar, M., \& Pompe Novak, M. (2018). Validated reverse transcription droplet digital PCR serves as a higher order method for absolute quantification of Potato virus Y strains. Analytical and Bioanalytical Chemistry, 410(16), 3815-3825.

Mehle, N., Gutiérrez-Aguirre, I., Prezelj, N., Delić, D., Vidic, U., \& Ravnikar, M. (2014). Survival and transmission of potato virus $\mathrm{Y}$, pepino mosaic virus, and potato spindle tuber viroid in water. Applied and Environmental Microbiology, 80(4), 1455-1462.

Mehle, N., \& Ravnikar, M. (2012). Plant viruses in aqueous environment-Survival, water mediated transmission and detection. Water Research, 46(16), 4902-4917.

Moazeni, M., Nikaeen, M., Hadi, M., Moghim, S., Mouhebat, L., Hatamzadeh, M., et al. (2017). Estimation of health risks caused by exposure to enteroviruses from agricultural application of wastewater effluents. Water Research, 125, 104-113.

Pfister, S., Bayer, P., Koehler, A., \& Hellweg, S. (2011). Environmental impacts of water use in global crop production: Hotspots and trade-offs with land use. Environmental Science and Technology, 45(13), 5761-5768.

Pradeep, P., \& Chulkyoon, M. (2016). Non-thermal plasmas (NTPs) for inactivation of viruses in abiotic environment non-thermal plasmas (NTPs) for inactivation of viruses in abiotic environment. Research Journal of Biotechnology, 11(6), 91-96.

Rashmei, Z., Bornasi, H., \& Ghoranneviss, M. (2016). Evaluation of treatment and disinfection of water using cold atmospheric plasma. Journal of Water and Health, 14(4), 609-616.

Ridoutt, B. G., Hadjikakou, M., Nolan, M., \& Bryan, B. A. (2018). From water-use to water-scarcity footprinting in environmentally extended input-output analysis. Environmental Science and Technology, 52(12), 6761-6770.

Rupar, M., Ravnikar, M., Tušek-Žnidarič, M., Kramberger, P., Glais, L., \& Gutiérrez-Aguirre, I. (2013). Fast purification of the filamentous Potato virus $\mathrm{Y}$ using monolithic chromatographic supports. Journal of Chromatography A, 1272, 33-40.

Scholthof, K. B. G., Adkins, S., Czosnek, H., Palukaitis, P., Jacquot, E., Hohn, T., et al. (2011). Top 10 plant viruses in molecular plant pathology. Molecular Plant Pathology, 12(9), 938-954.

Scholtz, V., Pazlarova, J., Souskova, H., Khun, J., \& Julak, J. (2015). Nonthermal plasma-A tool for decontamination and disinfection. Biotechnology Advances, 33(6), 1108-1119.

Shrestha, S., Shrestha, S., Shindo, J., Sherchand, J. B., \& Haramoto, E. (2018). Virological quality of irrigation water sources and pepper mild mottle virus and tobacco mosaic virus as index of pathogenic virus contamination level. Food and Environmental Virology, 10(1), 107-120. 
Stewart-Wade, S. M. (2011). Plant pathogens in recycled irrigation water in commercial plant nurseries and greenhouses: Their detection and management. Irrigation Science, 29(4), 267-297.

Syed Ab Rahman, S. F., Singh, E., Pieterse, C. M. J., \& Schenk, P. M. (2018). Emerging microbial biocontrol strategies for plant pathogens. Plant Science, 267, 102-111.

USEPA. (2006). Ultraviolet disinfection guidance manual for the final long term 2 enhanced surface water treatment rule. Washington, DC: USEPA.

World Economic Forum. (2017). The global risks report 2017. Insight report (12th ed.). Geneva: World Economic Forum.

Wu, Y., Liang, Y., Wei, K., Li, W., Yao, M., Zhang, J., et al. (2015). MS2 virus inactivation by atmospheric-pressure cold plasma using different gas carriers and power levels. Applied and Environmental Microbiology, 81(3), 996-1002.

WWAP. (2018). The United Nations World Water Development Report 2018: Nature-based solutions for water. Paris: WWAP.
Yasuda, H., Miura, T., Kurita, H., Takashima, K., \& Mizuno, A. (2010). Biological evaluation of DNA damage in bacteriophages inactivated by atmospheric pressure cold plasma. Plasma Processes and Polymers, 7(3-4), 301-308.

Zámocký, M., Gasselhuber, B., Furtmüller, P. G., \& Obinger, C. (2012). Molecular evolution of hydrogen peroxide degrading enzymes. Archives of Biochemistry and Biophysics, 525(2), 131-144.

Zimmermann, J. L., Dumler, K., Shimizu, T., Morfill, G. E., Wolf, A., Boxhammer, V., et al. (2011). Effects of cold atmospheric plasmas on adenoviruses in solution. Journal of Physics. D. Applied Physics, 44(50), 505201.

Publisher's Note Springer Nature remains neutral with regard to jurisdictional claims in published maps and institutional affiliations. 